\title{
Politics, Society and Violence: The Role of the Indian Police in the 2002 Gujarat Riots
}

\section{Siyaset, Toplum ve Şiddet: 2002 Gujarat Olaylarında Hindistan Polisinin Rolü Üzerine Bir İnceleme}

\author{
Osman Ülker ${ }^{1}$ (1)
}

${ }^{1}$ Corresponding author/Sorumlu yazar: Osman Ülker (Res. Asst.),

Kilis 7 Aralık University, Faculty of Theology, Philosophy And Religious Studies, Kilis, Turkey. E-mail: osmanulker@kilis.edu.tr

ORCID: 0000-0001-6938-1057

Submitted/Başvuru: 25.12.2021 Accepted/Kabul: 06.03 .2021

Citation/Atıf: Ulker, Osman. "Politics, Society and Violence: The Role of the Indian Police in the 2002 Gujarat Riots." Avrasya Incelemeleri Dergisi - Journal of Eurasian Inquiries 10, 1 (2021): 149-166.

https://doi.org/10.26650/jes.2021.007

\begin{abstract}
In the general elections held in India in 2019, the far-right Indian nationalist Narendra Modi managed to be re-elected as Prime Minister. Modi has been criticized for the anti-Islamic discourse he used during his rule and election process. Moreover, there are concerns that the anti-Muslim attitude will divide Indian society. There are justifications for these concerns, given Modi's political background. Modi and his BJP party are believed to be active in the violence that took place in the state of Gujarat in India in 2002. During the riots, more than 1,000 people lost their lives. According to reports, police officers did not stop attacks against Muslims and they helped Hindu mobs find lethal weapons. In this article, the role of the police will be discussed within the axis of the relationship between the state, politics and civil society. The main reason why the Gujarat riots were chosen as a case study is that the exclusionary policies of Modi across India were experienced at the regional level in 2002. Furthermore, the discriminatory action of police in the violence of the Gujarat riots was supported by Modi and his party. Therefore, it becomes important to examine the role of the police in these riots. The data, which was collected through the documentation method, will be discussed in relation to Rainer's policing theory. According to Rainer there are four main reasons for police abuse, which are: prejudice, bias, differentiation and discrimination. In addition, the politicization of Indian police will be examined to understand the implicit relationship between government and police abuse. As a result, it has been determined that when motivated ideologically, religiously and ethnically, the police organization acts by excluding certain segments of the society.
\end{abstract}

Anahtar kelimeler: India, Gujarat, violence, nationalism, Policing theories

Öz

2019'da Hindistan'da yapılan genel seçimlerde aşırı sağcı ve Hintli milliyetçi Narendra Modi yeniden Başbakan seçilmeyi başardı. Modi, iktidarı süresince ve seçim esnasında kullandığı İslam karşıtı söylem nedeniyle eleştirilmiştir. Dahası, onun bu Müslüman karşıtı tutumunun Hint toplumunu böleceğine dair endişeler var. Modi'nin siyasi geçmişi göz önüne alındığında, bu endişelerin meşru bir dayanağı olduğu görülür. Bağımsız raporlara göre Modi ve BJP partisinin 2002 
yılında Hindistan'ın Gujarat eyaletinde meydana gelen şiddet olaylarında aktif olduğuna dair kanıtlar mevcuttur. İsyan 2002 yılında Hindu hacıları taşıyan bir trenin yanmasıyla başlamıştı. Olayın ardından Müslümanlara yönelik şiddet bir yıl sürdü ve 1000'den fazla kişi hayatını kaybetti. Raporlara göre, polis memurları Müslümanlara yönelik saldırıları engellemedi ve hatta Hindu çetelerin silah bulması için yardım ettiler. Bu yazıda polisin rolü devlet, siyaset ve sivil toplum ilişkisi ekseninde tartışılacaktır. Gujarat isyanının bir vaka olarak seçilmesinin temel nedeni, Modi'nin günümüzde Hindistan geneline yayılan dışlama politikalarının o dönemde bölgesel düzeyde deneyimlenmiş olmasıdır. Üstelik bu süreçte, polisin Gujarat şiddetinde ayrımcı tutumu, Modi ve partisi tarafından desteklenmiştir. Bu nedenle isyanlarda polisin rolünü incelemek önem kazanmaktadır. Belgeleme yöntemiyle toplanan veriler, Rainer'in polislik teorisinde tartışılacaktır. Rainer'e göre polisin tacizinin dört ana nedeni vardır: Tarafgirlik, önyargı, farklılaşma ve ayrımcılık. Buna ek olarak, Hindistan polisinin siyasallaşması, hükümet ve polis tacizi arasındaki örtük ilişkiyi anlamak için incelenecektir. Sonuç olarak polis teşkilatının ideolojik, dini ve etnik yönden motive edildiğinde toplumun belirli kesimlerini dışlayarak hareket ettiği tespit edilmiştir.

Keywords: Hindistan, Gujarat, şiddet, milliyetçili, Polis teorileri

\section{GENIŞLETILMIŞ ÖZET}

2014 yılında iktidara gelen Narendra Modi, 2019 yılında yeniden Hindistan'ın Başbakanı olarak seçildi. Başbakan Modi, uzun yıllardır tartışmalı bir siyasetçi olmuştur. Milliyetçiliği sadece bir ideoloji ya da gelenek olarak değil, Müslümanlara karşı sistematik dışlama yapmak maksadıyla da kullanmaktadır. Bu sebeple milliyetçi parti BJP önderliğinde yeniden iktidara gelmesi, Hindistan'daki insan hakları ihlallerinin büyüyeceği yönünde endişeleri arttırdı. Özellikle Hint çetelerinin sık sık Müslümanlara saldırması, devlet tarafından tolere edilen bir gerçek. Özellikle polisin yaşanan saldırıları görmesine rağmen bunlara müdahale etmemesi, ayrımcılığın boyutlarını göstermektedir. Milliyetçi parti BJP ve Modi hükümetine yönelik endişeler sadece küçük olaylarla sınırlı değil. 20 yıl önce Modi, Hindistan'ın Gujarat eyalerinde Başkan iken bir yıla yakın devam eden şiddet olayları ve bu olaylarda yerel hükümetin ve polisin rolü, günümüzde artmakta olan tansiyona yönelik endişeleri haklı çıkaran önemli bir tarihi örnektir. "2002 Gujarat olayları” olarak bilinen şiddet yanlısı gösteriler, Hintli hacıları taşıyan bir trenin yanması sonucu patlak vermişti. Sonraki yıllarda yapılan çalışmalarda trenin kazara içerden başlayan bir yangınla tutuştuğu anlaşılmış olsa da, bu o dönemde Müslüman karşıtı şiddeti önlemeye yetersiz kalmıştır. Olaylarda binin üzerinde insan hayatını kaybetmiş, 60 binden fazla Müslüman eyaletten kaçarak sığınma kamplarına yerleşmek zorunda kalmıştır.

Çalışmanın birinci bölümünde Gujarat olayları ele alınmış ve bu olaylarda polisin rolü incelenmiştir. Yaşana olaylar üzerine hazırlanan raporlar, görgü tanıklarının ve mağdurların ifadesinden hareketle, Hint polisinin bilerek olaylara müdahale etmediğini ortaya koymaktadır. Saldırı bölgelerinden polis istasyonlarına yapılan telefon aramaları "sizi kurtarmakla ilgili bir emir almadık" cevabıyla karşılaşmış, polis gözetiminde Müslüman mahalleler tespit edilerek ateşe verilmiştir. Yine bu raporlarda, Modi'nin ve milliyetçi BJP parti mensuplarının olaylarda aktif rol aldığına dair işaretler bulunmuştur. Bunun üzerine Hindistan Yüksek Mahkemesi Modi hakkında bir soruşturma başlatmış, bir çok Avrupa ülkesi Modi’ye ülkeye girme yasağı 
koymuştur. Fakat Modi’ye karşı bu tavır onun Başbakan seçilmesi ile birlikte yumuşamıştır. Fakat günümüzde Modi ve BJP'nin açıktan Müslümanları hedef alan açıklamaları ve Müslümanlara ayrımcılığı meşrulaştıran kanunlar, 20. Yıldönümüne gelen Gujarat olaylarının bir benzerinin, bütün ülke sathında yaşanmasına yol açabileceği gerçeğini göstermektedir. Üstelik Modi’nin Müslümanlara yönelik polis şiddetini kışkırtması, benzer olayların çok daha büyük felaketler doğurma ihtimalini göstermektedir.

İkinci bölümde ise, polisliğin kötü kullanılması dört başlık altında toplanmıştır. Bunlar:

a. "Tarafgirlik": karşılıklı iki grup arasında çıkan olaylara müdahale eden polisin, bir tarafı diğer tarafa tercih ederek hareket ettiği durumlar için kullanılmaktadır. Polis, olaylara müdahale ederken, Hintli götericilere müdahale etmezken, Müslümanlara yönelik keyfi tutuklamalara gitmiştir.

b. "Önyargı": Yani bir grubun tamamının veya çoğunun suç davranışı potansiyeline sahip olduğu algısıdır. Hindistan konseptinde Sabarmati Ekspresi'nin Godhra'da yakılmasının ardından Gujarat'taki tüm Müslüman cemaati olaydan sorumlu tutulması bir tarafgirlik örneğidir. Üstelik yapılan incelemenin ardından yangının trenin içinde kazara çıktığı ortaya çıkmasına rağmen, bu yaklaşım değişmemiştir.

c. 'Farklılaşma': sosyal statülerine göre polisin davranışını bir gruptan diğerine değiştirmesidir. Örneğin Gujarat şiddeti sırasında Ahmedabad'daki ayaklanmalardan birinde çatışmalar o kadar şiddetlendi ki polis silah kullanmak zorunda kaldı. Ancak olayların ardından polisin daha çok Müslümanları hedef aldığı anlaşıldı. Bu ve benzeri örnekler, polisin şiddetin kaynağına farklı bir yaklaşım sergilediğini göstermektedir.

d. 'Ayrımcılık': polisin herhangi bir hukuki sebep olmaksızın bireylere veya belirli bir gruba yönelik önyargılı tutumlarıdır. Reiner ayrımcılık sürecini altı türe ayırır: kategorik, istatistiksel, geçişken, etkileşimsel, durumsal ve kurumsal. Hindistan'daki polis eylemlerinde kategorik ve kurumsal ayrımcılık ön plana çıkmaktadır. Kategorik ayrımcılık, ayrımcılığın somut anlamını ifade eder. Gujarat isyanları sırasında, Hindistan polisinin önyargılı tutumları, basitçe Müslümanlara yönelik kategorik ayrımcılık olarak açıklanabilir.

Gujarat olaylarında polislerin belirgin bir bicinde kurumsal olarak Müslümanlara yönelik ayrımcılık yapması, şiddeti arttıran ve daha çok insanın canını kaybetmesine yol açan bir olgudur. Üstelik kurumsal şiddeti ortaya çıkaran en önemli nokta, polisin dışlayıcı tutumunun yerel yönetim tarafından desteklenmiş olmasıdır. Bu durum ise polisin politize olması başlığında daha detaylı olarak incelenmiştir.

$\mathrm{Bu}$ başlıkta temel soru; eğer polis halkı denetliyor ise polisi kimin denetleyeceğidir. Polisin Müslümanlara karşı hukuk dişı tutumu, onu denetlemesi gereken kurum tarafından desteklendiğinde şiddetin büyümesi kaçınılmaz olmaktadır. Nitekim BJP'nin sivil toplum hareketi olarak çıktığı dönemden itibaren aşırıcı milliyetçi tutumu, iktidara geldikleri bölgelerde yönetim biçimi haline gelmekte, böylece polisin Müslümanlara karşı keyfi tutumu meşrulaşmaktadır. Hatta sistematik şiddetin karşısında duran kolluk kuvvetleri, iktidarın mobbing uygulamasına maruz kalmıştır. 
Sonuçta aşırı Hint milliyetçiliği, devletin ideolojisine dönüşürken, polislerin Müslümanlara karşı dışlayıcı uygulamaları normalleşmeye başlamaktadır. Çıkan olaylar, Hint toplumunu parçalamakta ve ülke içinde azınlık konumundaki Müslümanları güvensiz hale getirmektedir. Modi, 2002 yılında elindeki gücü şiddeti sonlandırmak için kullanmayarak, olayların büyümesine göz yummuş ve bu çatışmadan siyasi bir çıkar elde etmek istemiştir. Günümüzde bütün Hindistan'ı saran ayrımcılığın, büyük şiddet olaylarını çıkarma potansiyeli görülmeli ve ülkedeki polisin rolü yeniden gözden geçirilmelidir. 


\section{Introduction}

One of the sensitive scenes in the film Slumdog Millionaire is death of the protagonist's mother during some violence. While Jamal Malik (Dav Patel) and his brother were playing near their mother in the slum's laundry with their neighbors, a group of people attacked them. In the film, men were burned alive, women were killed by the use of sticks, and homes were looted. The scene is based on a true story known as the Mumbai (Bombay) riot of 1992. The riot started after demolishing the historical Babri Mosque. Hindus believe that the mosque was established on the birthplace of Rama, the seventh avatar of Vishnu. According to reports, more than 1,000 people were killed in this riot. ${ }^{1}$ Although the whole incident can be recounted in two minutes in the film, this communal violence has continued for the last half-century between Hindus and Muslims.

India is a country of paradoxes and contradictions. On the one hand, there is a legendary man, Mahatma Gandhi, who teaches to the whole world how the struggle for freedom can be peaceful. On the other hand, countless riots have occurred before and after the partition of India into two new states. At the beginning, it was believed that the partition was the solution to the problems, but never-ending violence has shown that the partition has made HinduMuslim relations worse than in the past. ${ }^{2}$ The Mumbai attack was not a single example of the clash between Hindus and Muslims. Communal violence occurs occasionally in many regions throughout India since the independence. ${ }^{3}$

1 Asghar Ali Engineer, "Srikrishna Commission Report: Painstaking Documentation", Economic and Political Weekly 33, no 33/34 (1998): 2215.

2 Yasmin Khan, The Great Partition: The Making of India and Pakistan (London: Yale University Press, 2007), 10 .

3 Stuart Corbridge, Nikhila Kalra, ve Kayoko Tatsumi, "The Search for Order: Understanding Hindu-Muslim Violence in Post-Partition India”, Pacific Affairs 85, no 2 (2012): 287-311. 
Figure 1: The number of Hindu-Muslim riots and deaths across Indian States ${ }^{4}$

\section{Figure 1: Number of Hindu-Muslim riots and riot deaths in India, 1980-} 2008

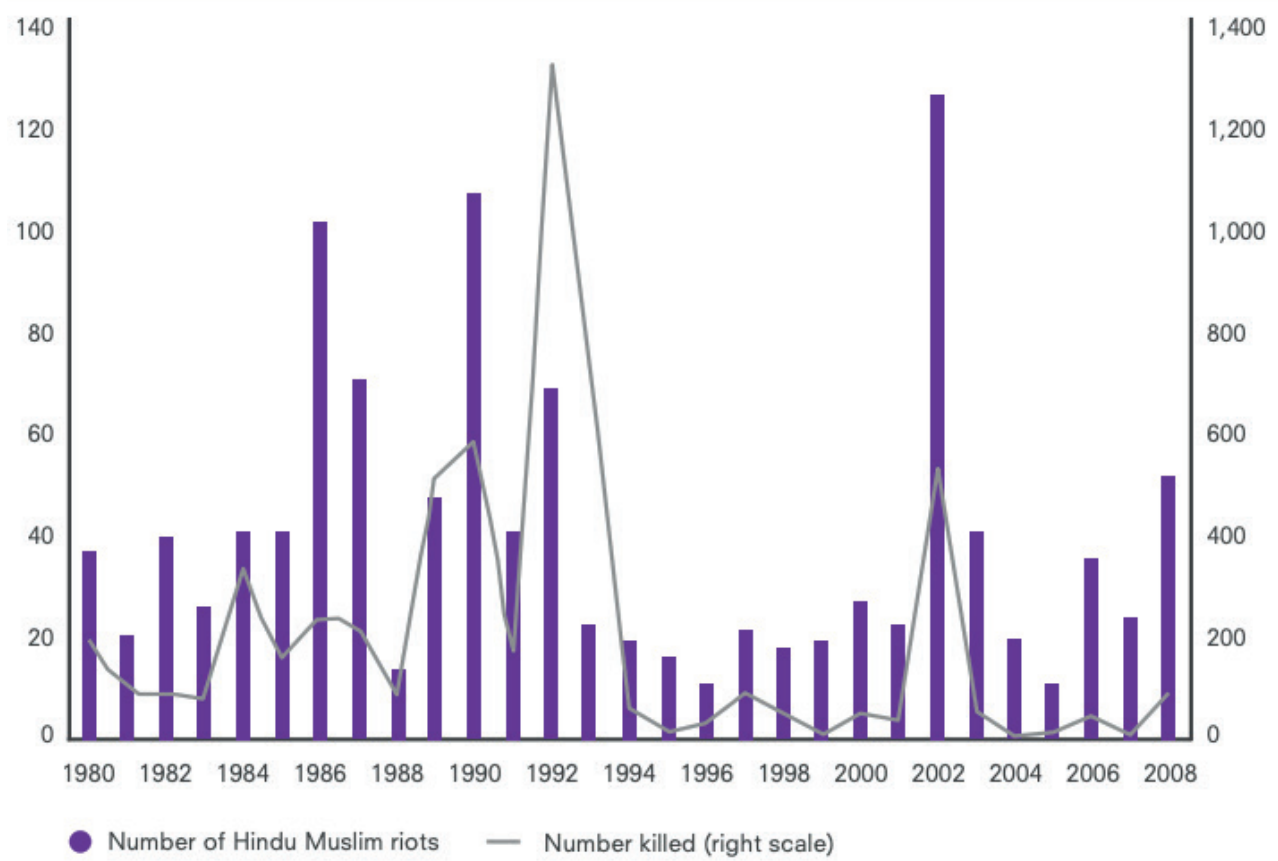

However, racist attacks against Muslims have turned to political pressure after the nationalist party, BJP, seized power in 2014. The government, formed by Modi, has explicitly targeted Muslims and started to enact laws excluding them. The first big step of the government against Muslims was to abolish Kashmir's autonomy. Kashmir, which remained a disputed region during the separation process of Pakistan and India, was declared as an autonomous region in Article 370. But Modi, who promised, in the 2019 elections. that this law would be lifted, kept his promise after he was elected. Thus, this mostly Muslim autonomous region, was attached to India. ${ }^{5}$ The Indian government, which wanted to control the region, changed elected officials and appointed governors from the center. A large number of soldiers were deployed and key figures were arrested in order to maintain full control of the area. Internet and phone lines were even shot down for a long time to prevent protests. ${ }^{6}$

4 Sonia Bhalotra, Irma Clots-Figueras and Lakshmi Iyer, Politician Identity, Policy Implementation and Human Development Outcomes, (International Growth Center: London, 2013), 3.

5 “Kashmir's special status: Five things to know", 05 July 2019, https://www.aljazeera.com/news/2019/8/5/ kashmir-special-status-explained-what-are-articles-370-and-35a. Accessed 22.02.2021

6 Billy Perrigo, "Supreme Court Orders Review of Internet Shutdown in Kashmir", Time, 10 January 2020, https:// time.com/5762751/internet-kashmir-supreme-court/. Accessed 20.02.2021 
The second major decision of the Modi government that directly targets Muslims is the introduction of the "new citizenship registration" system in Northeast India. With this decision, over 2 million Muslims from Bangladesh who resettled India during the colonial period were left without an identity and a state. ${ }^{7}$ Nonetheless, the announcement of "the Citizenship Amendment Law" aroused more concern. With this law, while the acceptance of Hindu and non-Muslim immigrants became easy, Muslims were excluded from being granted refugee status if they were refugees from neighboring countries. The government did not hide that this decision is purposely targeting Muslims. Shah, the leader of the BJP, supported the idea saying, "They carry out blasts [bombings] in our country and so many of our people die."" The real fear in these anti-Muslim measures is the gradual expansion the laws all over India. There are increasing fears that Muslims, who have been forced to live under the discrimination of Hindu nationalism, will no longer be able to continue their life in India. ${ }^{9}$

Moreover, this attitude towards Muslims has led to the exclusionary practices of the police, who are supposed to protect the civilian population. When people discriminated against discriminatory laws against Muslims, they faced harsh police intervention. There have been arbitrary arrests, policy raids and excessive force of power, even unnecessary use of weapons by the police. Important activists who defended Muslim rights were arrested without any justification. ${ }^{10}$ As a result, after the BJP party came to power under the leadership of Modi, an institutional exclusion was initiated against Muslims, and the rights restricted by law became practical with police intervention on the street. This situation raises concerns about the outbreak of major events in India. At this point, it is useful to recall an important event in the past. The events that took place in 2002 in Gujarat, the state that Modi ruled before he was elected as Prime Minister, constitute an example for the increasing tension in the country today. It is an example of how cooperation between the government and the police can turn into genocide against Muslims. For this reason, in this article, the 2002 Gujarat riots will be analyzed in the context of the relationship between the state, society and police. First, the role of the police in the Gujarat events will be examined. Then the attitude of the police will be compared with Robert Reiner's theory on policing.

\section{Gujarat Riots in 2002 and the Role of Police}

The trigger of the Gujarat riots was the torching of the Sabarmati Express in Godhra by an angry mob on 27 February 2002. Fifty-eight people, some of whom were women and

7 “'Shoot the Traitors' Discrimination Against Muslims under India’s New Citizenship Policy” (Human Right Watch, 2020.), 3.

8 Deepshikha Ghosh, “Amit Shah Termite Remark On Immigrants Unwanted, Says Bangladesh”, 24 September 2018, https://www.ndtv.com/india-news/amit-shah-termite-remark-on-immigrants-unwanted-says-bangladesh-1921088. Accessed 24.02.2021

9 Sarah Repucci, “A Leaderless Struggle for Democracy” (Washington: Freedom House, 2020), 2-3.

10 “'Shoot the Traitors” Discrimination Against Muslims under India’s New Citizenship Policy”, 43-49. 
children, were burnt alive. ${ }^{11}$ A large number of Hindu activists who were coming to Ayodhya for a political activity to establish a temple to Lord Rama on the Babri Masjid, which had been destroyed ten years ago, were passengers on a train. The police accused Muslims of attacking the train and imposed a curfew. One day after of the incident, violence broke out. Muslim shops and homes were looted and set on fire in Sabarmati and the walled city. On the same day, in Chamanpura-Asarwa, forty-three people were burnt alive and over 10,000 people set the Gulmarg Society area on fire. ${ }^{12}$ Henceforth, collective violence spread to other districts of Gujarat. By the end of the first week of March, 14 out of the 25 districts of Gujarat were affected by events and more than 600 people were killed. ${ }^{13}$ By the middle of March, 60,000 Muslims moved from Ahmedabad and other districts to relief camps. ${ }^{14}$ According the formal reports at the end of the events, 790 Muslims and 254 Hindus were killed, 2,500 were injured and another 223 people were missing. ${ }^{15}$ But, it is believed that the number is higher than those officially declared. ${ }^{16}$ The Gujarat government and security forces were criticized for failing to prevent the riots. The upper house of the Indian parliament unanimously voted a resolution to carry out a federal investigation in Gujarat. ${ }^{17}$ International organizations, such as Human Right Watch, blamed the local government and police for being 'directly involved in the killings of hundreds of Muslims since February 27'. ${ }^{18}$ Senior South Asia researcher for Human Rights Watch, Smita Narula, describes the situation, saying:

\begin{abstract}
"What happened in Gujarat was not a spontaneous uprising; it was a carefully orchestrated attack against Muslims. The attacks were planned in advance and organized with extensive participation of the police and state government officials." 19
\end{abstract}

Before evaluating the events, the questions, 'Who are the police?', and 'What are the responsibilities of police in society?' must be answered. It is hard to describe contemporary police in terms of their tasks. In the modern world, duties of police have expanded from promoting road traffic safety to fighting global terrorism. Nevertheless, the main idea of

11 "Scores Killed in India Train Attack", 27 September 2002, http://news.bbc.co.uk/2/hi/south_asia/1843591.stm. Accessed 24.02.2021

12 "India braces for religious violence", 28 September 2002, https://edition.cnn.com/2002/WORLD/asiapcf/ south/02/27/india.train/index.html. Accessed 23.02.2021

13 "Timeline of the Riots in Modi's Gujarat", The New York Times, 06 April 2014, blm. World, https://www.nytimes. com/interactive/2014/04/06/world/asia/modi-gujarat-riots-timeline.html. Accessed 10.02.2021

14 Achyut Yagnik ve Suchitra Sheth, "Whither Gujarat?", Economic and Political Weekly 37, no 11 (16 March 2002): 1010.

15 "Gujarat riot death toll revealed", 11 May 2005, http://news.bbc.co.uk/2/hi/south_asia/4536199.stm. Accessed 20.02.2021

16 Christophe Jaffrelot, "Communal Riots in Gujarat: The State at Risk?", Working paper, c. 17, (2003).

17 “Indian MPs Back Gujarat Motion”, 06 May 2002, http://news.bbc.co.uk/2/hi/south_asia/1970415.stm. Accessed 22.02.2021

18 "India: Gujarat Officials Took Part in Anti-Muslim Violence", Human Rights Watch, 30 April 2002, https:// www.hrw.org/news/2002/04/30/india-gujarat-officials-took-part-anti-muslim-violence. Accessed 19.02.2021

19 Idib 
police/policing is derived from the idea of social control. ${ }^{20}$ This term has a broad meaning and needs to be narrowed. Stan Cohen constricts its definition to "organised ways in which society responds to behaviour and people it regards as deviant, problematic, worrying, threatening, troublesome or undesirable in some way or another." ${ }^{21}$ In that sense, the police are one part of the social control devices in society. The main reason for social control is to continue social order. An exact description of police or the idea of policing in the axis of this term is "the set of activities aimed at preserving the security of a particular social order or social order in general". 22 Hence, the main point in definition of policing is governance of security. When the theoretical description of police and the role of the Indian police in the Gujarat riots are compared, the failure of police forces to provide sufficient contribution to the reestablishment of social order shows the opposite of what police should have done. In the reports investigating the Gujarat incidents, it is clear that the police did not do their job. The International Religious Freedom Report, for instance, claims that the police did little to stop the violence. ${ }^{23}$ Two quotes from different Human Rights Watch reports on the Gujarat riots show the role of police in the incidents:

\begin{abstract}
"The Gujarat police have initiated very few criminal investigations and have been largely non-responsive in cases where activists have lodged complaints about threats or attacks." ${ }^{24}$

"In Ahmedabad, Gujarat's commercial capital and the site of Human Rights Watch's investigations, many attacks took place within view of police posts and police stations. Human Rights Watch viewed several police posts less than fifty feet from the site of burnt Muslim-owned restaurants, places of businesses, and hotels in Ahmedabad."25
\end{abstract}

The example testimonies, which are given above, show clearly that the Indian police forces did not show the attitudes expected of them. Instead of providing social order, they became a trigger factor for the violence. Therefore, conventional definitions of the role of police do not suffice to explain why security forces could not have controlled the riots. In the following chapters, two policing theories will be examined to answer why the police did not provide social control of the mobs.

\title{
Discrimination Theory
}

20 Andrew Scull, Social Order/Mental Disorder: Anglo-American Psychiatry in Historical Perspective (Berkeley: University of California Press, 1989), 121.

21 Stanley Cohen, Visions of Social Control: Crime, Punishment and Classification (Cambridge: Polity Press, 1985), 1.

22 Robert Reiner, The Politics of the Police, 4th edition (Oxford ; New York: Oxford University Press, 2010$), 5$.

23 "India" (International Religious Freedom Report 2002, 2002), //2009-2017.state.gov/j/drl/rls/irf/2002/14023. htm. Accessed 20.02.2021

24 "Intimidation and Harassment of Witnesses, Human Rights Activists, and Lawyers Pursuing Accountability for the 2002 Communal Violence in Gujarat” (Human Right Watch, 24 April 2004), 2, https:/www.hrw.org/legacy/ backgrounder/asia/india/gujarat/gujarat0904.pdf. Accessed 21.02.2021

25 “'WE HAVE NO ORDERS TO SAVE YOU' State Participation and Complicity in Communal Violence in Gujarat" (Human Right Watch, April 2002), 22. https://www.hrw.org/reports/2002/india/gujarat.pdf. Accessed 23.02.2021 
The first theory is the transformation of discretion into discrimination. Police forces can use discretion while enforcing the law. In practice, this authority raises a concern: 'Does the use of discretion provoke discrimination?' Racism and discrimination by police always creates a polemic on the legitimacy of them. Discrimination of blacks by American police ${ }^{26}$ and Arabs by Israeli police ${ }^{27}$ show that it can be seen in different countries. Different social structures separated from majority groups, such as ethnic and religious minorities, immigrants and disadvantaged groups in a society are more open to police abuse and are less powerful to counteract both physically and by use of their rights. Differential exercise of police powers against the socially disadvantaged and relatively powerless is the product of bias stereotyping, and the amplification of the apparent deviance of these groups.$^{28}$ Various motivations must be sought in order to understand why the police take an exclusive attitude towards certain groups and to use their power against them. When we evaluate the incident in Gujarat in terms of Reiner's classification of exclusionary police practices, the role of the police in the Gujarat events could be made clearer. Reiner divided discriminatory attitudes of police into four groups: ${ }^{29}$

a. 'Prejudice': It is used for situations where the police, who intervene the clash between two mutual groups, prefer one side to the other.

b. 'Bias': the perception of all or most of the group as having potential for criminal behavior. In the Indian concept, after the burning of Sabarmati Express in Godhra, all of the Muslim community in Gujarat was deemed as being responsible for the incident. But after the investigation, it was revealed that the fire had been started accidentally inside the train. ${ }^{30}$ Nonetheless, the prejudice against Muslims has concealed the truth.

c. 'Differentiation': the changing behavior of police from one group to another according to their social status. For instance, during the Gujarat violence, in one of the riots in Ahmedabad, the clashes became so violent that police had to use guns. However, after the events, it was understood that the police mostly targeted Muslims. ${ }^{31}$ This and similar examples show that the police take a differentiating approach to the source of violence.

d. 'Discrimination': biased attitudes of police towards individuals or a certain group without any judicial reason. Reiner divides the discrimination process into six types: categorical, statistical, transmitted, interactional, situational, and institutional. ${ }^{32}$ In the case of police acts in India, categorical and institutional discrimination came into prominence. Categorical discrimination refers to the nominative meaning of discrimination. During the Gujarat riots,

26 Eric A. Stewart vd., "Neighborhood Racial Context and Perceptions of Police-Based Racial Discrimination Among Black Youth", Criminology 47, no 3 (2009): 847-87.

27 Badi Hasisi ve Ronald Weitzer, "Police Relations with Arabs and Jews In Israel", The British Journal of Criminology 47, no 5 (2007): 728-45.

28 Reiner, The Politics of the Police, 159.

29 Ibid, 160.

30 Barbara D. Metcalf and Thomas R. Metcalf, A Concise History of Modern India, 3. ed, Cambridge Concise Histories (Cambridge: Cambridge University Press, 2012), 280.

31 "Hindustan News", 03 May 2002.

32 Reiner, The Politics of the Police, 161. 
biased attitudes of Indian police can be explained simply as categorical discrimination of Muslims. Institutional discrimination, as Macpherson defines:

\begin{abstract}
"Institutional racism is the collective failure of an organization to provide an appropriate and professional service to people because of their colour, culture, or ethnic origin which can be seen or detected in processes, attitudes and behaviour which amount to discrimination through unwitting prejudice, ignorance, thoughtlessness, and racist stereotyping which disadvantages minority ethnic people." ${ }^{33}$
\end{abstract}

'Yeh andar ki baat hai, police hamare saath hai (it is an open secret, the police are on our side) ${ }^{34}$ is one of the slogans chanted during the riots. Due to the bias of the police during the demonstrations, Indian gangs entered the Muslim neighborhoods and harmed people. However, while this was happening, there were numerous witness statements that the police only watched and did not stop the events. ${ }^{35}$ Nevertheless, Institutional discrimination raises an important problem. If a group shows discriminative behavior against another group, a state can take precautions to prevent it, but institutional discrimination is shown directly by a state organ. Then who will prevent it? In other words, who will be policing the police?

\title{
Politicization Theory
}

James Vadackumchery argues the moral of police in developing countries stating that the elected government of a developing country, such as India, obtains a strong power over state institutions. When police feel political pressure, providing law and order and staying neutral becomes difficult for them. ${ }^{36}$ Nevertheless, when we examine the excessive use of police power in many countries, it is clear that questioning the moral of police is not limited to developing countries. Matter of fact, criticism against police brutality in the US, burst after George Floyd was killed during an arrest in 2020. It is claimed that some politicians protected the police who had killed Floyd. ${ }^{37}$ In France, when the police was criticized for using violence against "yellow vest protestors", Macron defended police action by rejecting to talk about violence: "Don't speak of 'repression' or 'police violence,' these words are unacceptable under the rule of law".38

33 Sir William Macpherson, "The Stephen Lawrence Inquiry” (Uk Secretary Of State For The Home Department, 1999), Https://Assets.Publishing.Service.Gov.Uk/Government/Uploads/System/Uploads/Attachment_Data/ File/277111/4262.Pdf. Accessed 23.02.2021

34 Teesta Setalvad, "When guardians betrays : the role of the police", Gujarat, the making of a tragedy, ed. Siddharth Varadarajan (New Delhi ; New York: Penguin Books, 2002), 177.

35 Asghar Ali Engineer, "Gujarat Riots in the Light of the History of Communal Violence", Economic and Political Weekly 37, no 50 (2002): 5053.

36 James Vadackumchery, Police Morality (Delhi: Kalpaz Publications, 2001), 205.

37 Peter Baker ve Thomas Kaplan, "Trump Defends Police, but Says He'll Sign Order Encouraging Better Practices", The New York Times, 11 June 2020, blm. U.S., https://www.nytimes.com/2020/06/11/us/politics/trump-bidenpolice.html. Accessed 24.02.2021

38 Pauline Bock, "Emmanuel Macron's Year of Cracking Heads", Foreign Policy, 29 Kasim 2019, https://foreignpolicy. com/2019/11/29/emmanuel-macrons-france-yellow-jackets-police-europe-year-of-cracking-heads/. 
It seems that the effect of politics on the police is a larger phenomenon. In fact, according to Rainer, politicization of the police is inevitable: "In a broader sense, all relationships with a power dimension are political, so policing is inherently and inescapable political." 39

The second policing theory to understand the behavior of police in the Gujarat violence is the politicization of police. In this respect, some Hindu organizations must be examined to understand how the police are politicized. The most important of them is Rashtriya Swayamsevak Sangh (RSS) (National Volunteer Organization). RSS was founded in 1925 as a national movement against British colonialism. ${ }^{40}$ It has become one of the most important national organizations during and after the partition..$^{41}$ In this organisation, the idea of Sangh Parivar (Family of Organization) has emerged. Thus, a network was created between national Hindu organizations from politics to charity foundations. ${ }^{42}$ One of them is Vishwa Hindu Parishad (VHP) (World Hindu Council) which was founded by RSS leaders in $1964 .{ }^{43}$ It has carried Hindu nationalist discourse to a religious platform. The last organization is Bharatia Janata Party (BJP) (Indian People's Party). It was founded in 1980 and become popular throughout India later, in the 1990s. It is important to note that, there has been a division of labor between these three organizations as Manjari Katju describes:

"The RSS, the BJP, and the VHP work as three distinct bodies and separate constitutions, organizational structures, and work patterns. It cannot be denied, however, that in terms of membership, ideology, and agenda of action, there is an overlap between the three, and that the RSS has played a parenting role in shaping the other two organizations." ${ }^{\prime 4}$

According to Mc Donnel and Carera, the source of the BJP is the RSS and it is possible to trace RSS's ideological roots back to the 19th century. According to RSS ideology, Hindus are not a religious group, but are victims, oppressed throughout the history, under strong foreign elites such as Muslims and the British. ${ }^{45}$ This statement has led some authors to think that RSS has an anti-colonial structure. ${ }^{46}$ But when looking at the origins of the RSS, it is seen that it does not participate in anti-colonial movements. Although the RSS defends the Hindu supremacy, it did not take part in the anti-colonial block against the British and had an apolitical image in its first period. ${ }^{47}$ In the next period, the movement was affected by fascism in Mussolini Italy. Moonje, one of the important names of the movement at that time, went

39 Reiner, The Politics of the Police, 32.

40 Jean A. Curran, "The RSS: Militant Hinduism", Far Eastern Survey 19, no 10 (1950): 93.

41 Chetan Bhatt, Hindu Nationalism: Origins, Ideologies and Modern Myths (Oxford: Berg, 2001), 4.

42 John McLeod, The History of India, First Edition (Westport, Conn: Greenwood, 2002), 171.

43 Rajyasri Rao, "Profile: The Vishwa Hindu Parishad”, 07 March 2002, http://news.bbc.co.uk/2/hi/south_ asia/1860202.stm.

44 Manjari Katju, Vishva Hindu Parishad and Indian Politics (Hyderabad: Orient Longman, 2003), 2.

45 Duncan Mc Donnel and Luis Cabrera, "The right-wing populism of India's Bharatiya Janata Party (and why comparativists should care)" Democratization 26, no 3 (2019): 485

46 Curran, "The RSS", 93.

47 Bhatt, Hindu Nationalism. 115-116. 
to Italy and met with Mussolini and carried his ideological and organizational structure to India. ${ }^{48}$ The RSS's relationship with fascism wasn't only with Mussolini in the past. Sadashiv Golwalker, president of the RSS between 1940 and 1973, wrote a text praising Hitler and defined Christian and Muslim elements as "hostile elements."

However, the fact that the religious and nationalist discourse, which is widespread in developing countries, affected the lower classes, increased the vote rates, and worked in the opposite direction in the BJP's India. People who vote for the BJP, compared to members of other parties, paint a distinctly more religious portrait, adopting statist economic policies, and are less engaged with people of other religions. In addition, according to the survey studies conducted on BJP voters in different years, the BJP represents the upper castes and middle class. This evaluation, which became stronger with each election, turned to fact after 2014. It can be said that the middle and upper middle classes formed the electoral profile of the BJP, which received the majority of the votes in the cities especially in the 2014 elections..${ }^{50}$ Chipper explains the success of the BJP among middle and upper classes as follows:

"The success of the party can, instead, be attributed to the ability of the party to forge a coalition between religious groups and the economic interests of middle classes." ${ }^{11}$

We do believe that one of the underlying causes of losing the political neutrality of the police is that the BJP was the ruling party in Gujarat in 2002. The Chief Minister of Gujarat was former RSS member, Narenda Modi. ${ }^{52}$ The organic bond between Indian nationalist movements under Sangh Parivar's notion meant that the riots become insoluble in both the public space and the political arena. As a result, the police have inescapably been affected by the political developments. Politicization of the police has occurred in several ways. The first one is staffing or penetration in police offices. There are allegations that the Modi had meetings with police officers during the riots and gave false assurance. ${ }^{53}$ But it's not a new phenomenon or a local problem related to just Modi. With the BJP increasing its power in the political arena, it is seen that well-organized Hindu nationalism began to "infiltrate" state institutions, especially in the $90 \mathrm{~s}$ :

"The mid- to late-1990s have witnessed the extraordinary rapidity and zeal with which BJP controlled states, and the Hindutva movements unleashed within them, have inducted their

48 Idib. 224.

49 Donnel and Luis Cabrera, "The right-wing populism of India's Bharatiya Janata Party”, 486.

50 Pradeep Chhibber, "Who Voted for the Bharatiya Janata Party?", British Journal of Political Science 27, no 4 (October 1997); Pradeep Chipper ve Rahul Verma, “The BJP's 2014 Resurgence”, in Electoral Politics in India: The Resurgence of the Bharatiya Janata Party (Taylor \& Francis, 2017), 15-33; E Sridharan, "Electoral Politics in India", in Middle-Class Votes for BJP (Routledge India, 2017), 270-81.

51 Chhibber, "Who Voted for the Bharatiya Janata Party?", 639.

52 Jaffrelot, "Communal Riots in Gujarat". 2.

53 Engineer, "Gujarat Riots in the Light of the History of Communal Violence", 5053. 
vision of 'Hindu rashtra' into the institutions of state governments and civil society" 54

The general opinion is that, after coming to power with the support of a large majority in 1998, the BJP tried to keep police forces under its control. The BJP has recruited officers who are pro-RSS or nationalist to the police cadres. ${ }^{55}$ Jaffrelot cites that the nationalist Hindus have occupied not only police headquarters but also other state organs. Hence, it is very normal, according to Jaffrelot, for police to respond by saying, 'We have no orders to save you' to the Muslims who phone them. ${ }^{56}$ Another factor of politicization of police by the BJP government is that the BJP used its political power to put pressure on police not to act against Hindu mobs. According to eyewitness testimonies and NGO's reports, individual police officers who have tried to prevent riots, by taking action against angry Hindu mobs to protect Muslims and keep the peace, or arrested members of the RSS, the VHP, or the BJP for being involved in the riots, have been transferred and shifted.$^{57}$ For instance, 27 police officers were transferred who had arrested the VHP leaders. ${ }^{58}$ In another interesting case reported by Human Rights Watch, police officer Rahul Sharma, who successfully prevented a mob attack upon a madrasa and rescued 400 people who were stuck in the building, was transferred to different stations five times in a year. ${ }^{59}$

The local leader cadres of the RSS, the VHP, and the BJP have taken an active role in the riots. According to Jaffrelot, voter lists have been used to determine Muslims' addresses, the BJP leaders have participated with the mobs in the streets, and political authorities have prevented the intervention of police while riots continue. The most common assertion about the sided attitude of police is that the BJP has wanted to use events for their own interests. He adds:

\footnotetext{
"The Modi government's involvement in Hindu/Muslim violence- a fact that largely explains its exceptional scope- is part of an unavowed but easily reconstructed political strategy. His party, the BJP, and the Hindu nationalist movement on the whole, honed this strategy between 1989 and 1991 when their activists worked at provoking anti-Muslim riots as election time approached. This violence in effect polarises society along a religious line of cleavage, which generally leads the Hindu majority, with a heightened sense of Hindu identity, to vote more in favour of the BJP. This explains the correlation between the election calendar and the cycle of riots." ${ }^{60}$
}

54 Bhatt, Hindu Nationalism, 178.

55 Setalvad, "When guardians betrays : the role of the police", 178.

56 Jaffrelot, "Communal Riots in Gujarat", 17:6.

57 Setalvad, "When guardians betrays : the role of the police", 49.

58 A.g.e., 194.

59 “'WE HAVE NO ORDERS TO SAVE YOU' State Participation and Complicity in Communal Violence in Gujarat", 49.

60 Jaffrelot, "Communal Riots in Gujarat", 17:2. 
Another kind of relationship between politics and exclusionary practices of the police, as Jafrelott expresses, emerges in the relationship between violence and local elections. There are also indications supporting that Narenda Modi, now Prime Minister of India, aimed to increase the vote of Indian nationalists in the elections by increasing tensions in Gujarat in 2002. Modi resigned shortly after the events of Gujarat, leading to re-elections. ${ }^{61}$ A report established by The Independent Fact Finding Mission argues that nearly half of the 106 major riots in Gujarat between 1987 and 1991 emerged during the election process. ${ }^{62}$ It seems that, as the elections approached, the demonstrations were used as an opportunity to gain nationalist votes. This fact arises as a result of the politicization of the police.

\section{Conclusion}

In this study, Gujarat riots in 2002 were examined in terms of the scale of the abuse of policing. It is understood how the whole society is harmed when the police force, which should protect the lives and property of citizens without discrimination on the basis of race, religion or gender, is exclusionary against a part of the society. Moreover, it has been observed that the police's engagement in politics by going beyond the law, while benefiting some politicians, creates a security gap in the society. The events that took place in the state of Gujarat in India showed that if politicians control state institutions in line with their own interests, social turmoil could cause great damage. This damage should not be considered as just physical. People's memories, their trust in the state and their expectations for the future are also damaged. In addition, when hatred towards a group of people, which is produced by the state, is attributed to the society, irreversible wounds occur and cause the society to break down. The events in Gujarat also increased the Hindu-Muslim polarization and led to the exclusion of the minority Muslims by the state.

The nationalist party, the BJP, which was responsible for the Gujarat riots, has been ruling India since 2014. Prime Minister Modi was banned from the US and many EU countries as he was held responsible for the Gujarat incidents, but these restrictions against him were lifted after he won the elections. But being Prime Minister did not change Modi. Systematic discrimination against Muslims by the state has been going on since 2014. The enacted anti-Muslim laws and the arbitrary practices of the police force against Muslims reveal the concerns that a new Gujarat incident could occur throughout the country. In order to prevent new violence against Muslims, the police are expected not to surrender to ideological pressures and to act in accordance with the rule of law.

61 “Gujarat chief minister resigns", 19 Temmuz 2002, http://news.bbc.co.uk/2/hi/south_asia/2139008.stm. Accessed 24.02.2021

62 Kamal Mitra C., S. P. Shukla, ve K. S. Subramanian, "Dr Kamal Mitra Chenoy, S. P. Shukla, K. S. Subramanian, Achin Vanaik" (The Independent Fact Finding Mission, 2002). 
Peer-review: Externally peer-reviewed.

Conflict of Interest: The author has no conflict of interest to declare.

Grant Support: The author declared that this study has received no financial support.

Hakem Değerlendirmesi: Dış bağımsız.

Çıkar Çatışması: Yazar çıkar çatışması bildirmemiştir.

Finansal Destek: Yazar bu çalışma için finansal destek almadığını beyan etmiş̧ir.

\section{References/Kaynakça}

Baker, Peter, and Thomas Kaplan. “Trump Defends Police, but Says He'll Sign Order Encouraging Better Practices”. The New York Times, 11 June 2020, blm. U.S. https:/www.nytimes.com/2020/06/11/us/politics/ trump-biden-police.html.

Bhatt, Chetan. Hindu Nationalism: Origins, Ideologies and Modern Myths. Oxford: Berg, 2001.

Bock, Pauline. "Emmanuel Macron's Year of Cracking Heads". Foreign Policy, 29 November 2019. https:// foreignpolicy.com/2019/11/29/emmanuel-macrons-france-yellow-jackets-police-europe-year-of-crackingheads/.

Chhibber, Pradeep. "Who Voted for the Bharatiya Janata Party?" British Journal of Political Science 27, no 4 (October 1997): 619-59.

Chipper, Pradeep, and Rahul Verma. "The BJP's 2014 Resurgence". in Electoral Politics in India: The Resurgence of the Bharatiya Janata Party, 15-33. Taylor \& Francis, 2017.

Cohen, Stanley. Visions of Social Control: Crime, Punishment and Classification. Cambridge: Polity Press, 1985.

Corbridge, Stuart, Nikhila Kalra, and Kayoko Tatsumi. "The Search for Order: Understanding Hindu-Muslim Violence in Post-Partition India”. Pacific Affairs 85, no 2 (2012): 287-311.

Curran, Jean A. "The RSS: Militant Hinduism”. Far Eastern Survey 19, no 10 (1950): 93-98. doi:10.2307/3023941.

Engineer, Asghar Ali. "Gujarat Riots in the Light of the History of Communal Violence". Economic and Political Weekly 37, no 50 (2002): 5047-54.

"Srikrishna Commission Report: Painstaking Documentation". Economic and Political Weekly 33, no 33/34 (1998): 2215-16.

Ghosh, Deepshikha. “Amit Shah Termite Remark On Immigrants Unwanted, Says Bangladesh”, 24 September 2018. https://www.ndtv.com/india-news/amit-shah-termite-remark-on-immigrants-unwanted-saysbangladesh-1921088.

“Gujarat chief minister resigns”, 19 July 2002. http://news.bbc.co.uk/2/hi/south_asia/2139008.stm.

“Gujarat riot death toll revealed", 11 May 2005. http://news.bbc.co.uk/2/hi/south_asia/4536199.stm.

Hasisi, Badi, and Ronald Weitzer. "Police Relations with Arabs and Jews In Israel". The British Journal of Criminology 47, no 5 (2007): 728-45.

"Hindustan News", 03 May 2002.

“India”. International Religious Freedom Report 2002.

https://2009-2017.state.gov/j/drl/rls/irf/2002/14023.htm.

"India braces for religious violence", 28 February 2002. https:/edition.cnn.com/2002/WORLD/asiapcf/ south/02/27/india.train/index.html. 
"India: Gujarat Officials Took Part in Anti-Muslim Violence". Human Rights Watch, 30 April 2002. https:// www.hrw.org/news/2002/04/30/india-gujarat-officials-took-part-anti-muslim-violence.

“Indian MPs Back Gujarat Motion”, 06 May 2002. http://news.bbc.co.uk/2/hi/south_asia/1970415.stm.

"Intimidation and Harassment of Witnesses, Human Rights Activists, and Lawyers Pursuing Accountability for the 2002 Communal Violence in Gujarat”. Human Right Watch, 24 April 2004. https://www.hrw.org/ legacy/backgrounder/asia/india/gujarat/gujarat0904.pdf.

Jaffrelot, Christophe. “Communal Riots in Gujarat: The State at Risk?” Working paper. C. 17, 2003.

"Kashmir's special status: Five things to know”, 05 July 2019. https://www.aljazeera.com/news/2019/8/5/ kashmir-special-status-explained-what-are-articles-370-and-35a.

Katju, Manjari. Vishva Hindu Parishad and Indian Politics. Hyderabad: Orient Longman, 2003.

Khan, Yasmin. The Great Partition: The Making of India and Pakistan. London: Yale University Press, 2007.

Macpherson, Sir William. "The Stephen Lawrence Inquiry". UK Secretary of State for the Home Department,1999. https://assets.publishing.service.gov.uk/government/uploads/system/uploads/attachment_ data/file/277111/4262.pdf.

McDonnell, Duncan, and Luis Cabrera. "The right-wing populism of India's Bharatiya Janata Party (and why comparativists should care)". Democratization 26, no 3 (03 April 2019): 484-501.

McLeod, John. The History of India. First Edition. Westport, Conn: Greenwood, 2002.

Metcalf, Barbara D., and Thomas R. Metcalf. A Concise History of Modern India. 3. ed. Cambridge Concise Histories. Cambridge: Cambridge University Press, 2012.

Mitra C., Kamal, S. P. Shukla, and K. S. Subramanian. "Dr Kamal Mitra Chenoy, S. P. Shukla, K. S. Subramanian, Achin Vanaik". The Independent Fact Finding Mission, 2002.

Perrigo, Billy. "Supreme Court Orders Review of Internet Shutdown in Kashmir". Time, 10 January 2020. https://time.com/5762751/internet-kashmir-supreme-court/.

Rao, Rajyasri. "Profile: The Vishwa Hindu Parishad”, 07 Mart 2002. http://news.bbc.co.uk/2/hi/south_ asia/1860202.stm.

Reiner, Robert. The Politics of the Police. 4th edition. Oxford ; New York: Oxford University Press, 2010.

Repucci, Sarah. "A Leaderless Struggle for Democracy”. Washington: Freedom House, 2020.

"Scores Killed in India Train Attack", 27 February 2002. http://news.bbc.co.uk/2/hi/south_asia/1843591.stm.

Scull, Andrew. Social Order/Mental Disorder: Anglo-American Psychiatry in Historical Perspective. Berkeley: University of California Press, 1989.

Setalvad, Teesta. "When guardians betrays : the role of the police". in Gujarat, the making of a tragedy, editor Siddharth Varadarajan, 177-210. New Delhi ; New York: Penguin Books, 2002.

“ 'Shoot the Traitors' Discrimination Against Muslims under India's New Citizenship Policy”. Human Right Watch, 2020.

Sridharan, E. "Electoral Politics in India". in Middle-Class Votes for BJP, 270-81. Routledge India, 2017.

Bhalotra Sonia, Irma Clots-Figueras and Lakshmi Iyer, Politician Identity, Policy Implementation and Human Development Outcomes, International Growth Center: London, 2013.

Stewart, Eric A., Eric P. Baumer, Rod K. Brunson, and Ronald L. Simons. "Neighborhood Racial Context and Perceptions of Police-Based Racial Discrimination Among Black Youth". Criminology 47, no 3 (2009): $847-87$. 
"Timeline of the Riots in Modi's Gujarat". The New York Times, 06 Nisan 2014, blm. World. https://www. nytimes.com/interactive/2014/04/06/world/asia/modi-gujarat-riots-timeline.html,

Vadackumchery, James. Police Morality. Delhi: Kalpaz Publications, 2001.

“"WE HAVE NO ORDERS TO SAVE YOU' State Participation and Complicity in Communal Violence in Gujarat”. Human Right Watch, April 2002. https://www.hrw.org/reports/2002/india/gujarat.pdf.

Yagnik, Achyut, and Suchitra Sheth. "Whither Gujarat?" Economic and Political Weekly 37, no 11 (16 March 2002): 1009-11. 